\title{
Perspektif Multidimensional Pendidikan Pembangunan Berkelanjutan: Pemikiran Awal Konsep dan Penerapan
}

\author{
Iskandar Agung \\ Puslitjaknov-Balitbang Kemdiknas
}

\begin{abstract}
Abstrak: Pembangunan merupakan istilah yang dikemukakan oleh berbagai pihak sebagai upaya mencapai perubahan masyarakat ke arah kehidupan yang lebih baik. Pembangunan kerapkali dilaksanakan secara multidimensional, dalam arti meliputi berbagai dimensi kehidupan (ekonomi, sosial, pendidikan, politik, kesehatan, dan sebagainya), meski keseluruhan bermuara pada upaya menuju perbaikkan, kemajuan dan kesejahteraan hidup masyarakat penerimanya. Namun tidak jarang fenomena di sekitar memperlihatkan, keberhasilan suatu pembangunan kurang dapat dipertahankan, terancam kesinambungannya, dan bahkan dirusak oleh sebagian anggota masyarakat penerimanya. Di samping itu, pembangunan yag dilaksanakan pun tidak hanya membawa dampak positif, tetapi juga negatif dalam kehidupan masyarakat. Atas dasar itu diperkenalkan konsepsi pembangunan berkelanjutan (sustainable development) dengan tujuan agar pembangunan dapat dijaga, dipelihara, dan bahkan dikembangkan keberlanjutannya untuk kepentingan generasi masa kini maupun akan datang. Salah satu unsur potensial untuk menanamkan nilai dan tujuan pembangunan itu adalah melalui bidang pendidikan, yang dikenal dengan sebutan pendidikan pembangunan berkelanjutan (education sustainable development). Belum terdapat kejelasan konsepsional mengenai istilah pendidikan pembangunan berkelanjutan tersebut yang dapat digunakan sebagai pedoman atau acuan operasionalisasinya oleh berbagai pihak di lapangan. Atas dasar itu tulisan ini bermaksud mengemukakan suatu pemikiran mengenai pengertian pembangunan berkelanjutan serta cara untuk menyebarluaskan nilai dan tujuan yang terkandung dalam dimensi pembangunan melalui jalur pendidikan, terutama mengintegrasikannya ke dalam kegiatan intra dan ekstrakurikuler.
\end{abstract}

Kata kunci: pembangunan, pembangunan berkelanjutan, multidimensional, pendidikan .

Abstract: Development is a term expressed by all parties to promote the effort to create changes in the public toward a better life. Implementation of the Development is often performed multidimensionally in which most of the aspects in life (such as economy, social, education, politic, health, etc) are covered therein. Even though all of the Developments are aimed to improve, advance and achieve the welfare of the target society but in reality it is often found that a success in a Development is not followed by proper care and maintenance, worst of all, it is even threatened or vandalized by some of the irresponsible and reckless members of the society. In addition, it must be admitted that not all Developments can give positive impact to the society, some of which even create negative impacts against their life. On the basis of the premises mentioned above, it is necessary to introduce the concept of Sustainable Development so as to make sure that the Development will be properly cared-for, maintained, and even continued to the next level for the sake of the present and the future generations. One of the potential elements which can be used for implanting the values and objectives of the Development into the heart and mind of the society is Education, which is known as Education Sustainable Development. However, there has been no clear conception yet about the Education Sustainable Development which can be used as the guidelines and references at operational level by relevant parties. Therefore, this writing is intended to offer a concept of Education Sustainable Development, and the method for promoting the values and objectives of the Development through Education, especially are integrated into the intra and extracurricular activities.

Key words: development, sustainable development, multidimensional, education 


\section{Pendahuluan}

Education Sustainable Development (ESD) atau pendidikan pembangunan berkelanjutan, merupakan suatu konsep yang berkembang sejak dua dasawarsa lalu. Melalui pencetusan ESD diharapkan proses pembangunan yang dilaksanakan oleh suatu masyarakat lebih bertumpu pada kesadaran dan sikap menciptakan, menjaga, merawat keberhasilan dan membangun kesinambungan kehidupan masa kini dan masa depan yang lebih baik. Inisiatif munculnya konsep ESD memang terkait dengan proses dan hasil pembangunan yang berkesinambungan, dengan senantiasa antisipatif dan adaptif terhadap perubahan lokal, regional, dan global. Di samping itu, pembangunan berkelanjutan merupakan upaya untuk mengeliminir segenap dampak negatif yang timbul dari pelaksanaan pembangunan yang kurang terkendali dan destruktif.

Seperti diketahui, upaya meningkatkan dan memajukan suatu masyarakat dilakukan melalui pembangunan yang dapat dimengerti sebagai suatu proses perubahan yang terencana atau disengaja, di mana ide/gagasan, metode, dan teknik baru dintroduksi dan dikomunikasikan ke dalam suatu masyarakat agar berbagai segi kehidupan dapat meningkat. Melalui pembangunan berlangsung upaya untuk mengubah dari kondisi kehidupan tertentu ke kondisi kehidupan lain yang dinilai lebih baik. Implisit, pembangunan merupakan suatu persentuhan antar-sistem, yakni sistem yang terkandung dalam suatu program pembangunan di satu sisi, bersentuhan dengan sistem lainnya di sisi lain, baik fisik maupun nonfisik.

Dengan sendirinya pelaksanaan pembangunan tidak berhenti sampai di situ saja, melainkan berkonsekuensi logis terhadap munculnya ketidakseimbangan (dis-equilibrum) dan perubahan dalam sistem semula (fisik maupun nonfisik) yang terkenanya. Persoalannya, ke mana arah ketidakseimbangan dan perubahan yang terjadi? Apakah proses pembangunan yang dilaksanakan lebih mengarah pada hasil dan dampak positif, atau sebaliknya negatif dalam kehidupan penerimanya? Suatu proses pembangunan dinyatakan berdampak positif apabila ketidakseimbangan sistem semula mengarah pada keseimbangan yang baru dan dirasakan manfaatnya. Sebaliknya berdampak negatif apabila proses pembangunan yang dilaksanakan membawa keguncangan dan tidak atau kurang dirasakan manfaatnya, bahkan dianggap menimbulkan kesengsaraan bagi sistem sosial yang terkenanya.

Sistem fisik mengacu pada kondisi dan situasi lingkungan fisik, sedangkan nonfisik mengacu pada berbagai aspek kehidupan yang didukung oleh suatu sistem sosial yang berada di sekitarnya. Persoalannya, kedua sistem tersebut merupakan suatu kesatuan yang saling berhubungan satu sama lain secara sinergis. Vayda (1985) mengemukakan, bahwa manusia melakukan strategi adaptasi terhadap lingkungan di sekitarnya, sehingga dapat dipandang sebagai pola dari dan pola bagi perwujudan perilaku yang selaras dengan lingkungannya itu. Atau Parsons (1971) dengan konsep hirarkhi sybernatika menjelaskan, bagaimana manusia secara biologis mengembangkan strategi adaptasi terhadap lingkungan fisik di sekitar, menjadikan sebagai bagian dalam membentuk keperibadian diri, mewujudkan integrasi sosial sebagai kesatuan hidup, dan mempertahankan pola bagi kelangsungan hidup. Implikasinya, perubahan lingkungan fisik (disengaja maupun tidak disengaja, terencana maupun tidak terencana) secara langsung akan mengubah kehidupan nonfisik sebagai hasil strategi tersebut.

Lalu, bagaimana proses pembangunan yang perlu dilaksanakan agar dapat mengoptimalkan hasil dan dampak positif, sebaliknya meminimalisir dampak negatif yang ditimbulkan? Untuk itu, pembangunan tidak harus didekati dari satu sisi semata, tetapi multidimensional. Proses pembangunan tidak lagi dipandang sebagai ceteris paribus, dalam arti cukup memusatkan perhatian dan analisisnya terhadap unsur-unsur yang bersifat ekonomis berupa peningkatan produktivitas (sehingga dengan sendirinya diasumsikan akan meningkatkan pendapatan), melainkan perlu melibatkan analisisnya secara multidimensional, komprehensif, dan integral melibatkan analisisnya terhadap faktor nonekonomis (Myrdal, 1973). Makna konseptual pembangunan berkelanjutan perlu didekati secara menyeluruh dengan meliputi berbagai dimensi, sesuai dengan kompleksitas pelaksanaan 
pembangunan itu sendiri. Di samping itu, keberhasilan pembangunan pun perlu dijaga, dipertahankan, dan dirawat keberhasilan dan kesinambungannya, sehingga benar-benar bermanfaat bagi peningkatan kesejahteraan hidup masa kini dan mendatang. Atas dasar itu nilai dasar dan tujuan dalam pembangunan perlu ditanamkan kepada khalayak luas, termasuk salah satunya melalui jalur pendidikan.

Dalam konteks yang terakhir itu perlu dikembangkan suatu pengertian mengenai pembangunan berkelanjutan. Meski sejauh ini istilah pembangunan berkelanjutan sudah didengungkan oleh berbagai pihak, namun masih belum memiliki kejelasan konseptual. Makna pembangunan berkelanjutan masih perlu dipikirkan secara mendalam dan sistematis, baik secara konseptual maupun operasionalisasinya, sehingga dapat dijadikan acuan untuk penyebarluasannya, terutama mensosialisasikan dan menanamkan melalui jalur pendidikan. Berkenaan dengan hal itu, tulisan di bawah ini selanjutnya akan menjabarkan mengenai pengertian tentang pembangunan berkelanjutan, pendidikan pembangunan berkelanjutan (education sustainable developmen/ESD), dan upaya penerapannya di bidang pendidikan.

Tulisan bertujuan: 1) mengemukakan konsep pembangunan berkelanjutan dengan perspektif multidimensional; 2) mengemukakan peran pendidikan dalam menyebarluaskan dan menanamkan nilai dasar dan tujuan penerapan pembangunan; dan 3) mengemukakan model konseptual penerapan pembangunan berkelanjutan terkait dengan kegiatan intrakurikuler dan ekstrakurikuler. Pemikiran yang diajukan dalam tulisan ini dilakukan melalui pendekatan kepustakaan yang terkait dengan fokus pembahasan, terutama dalam memaparkan konsep mengenai pembangunan berkelanjutan. Di samping itu, meski tulisan mengemukakan suatu pemikiran penerapan melalui intrakurikuler dan ekstrakurikuler, namun masih bersifat konseptual. Artinya, pemikiran yang diketengahkan belum mengalami pengujicobaan di lapangan. Meski demikian diharapkan model yang diajukan dapat digunakan sebagai acuan dalam menerapkan konsep pembangunan berkelanjutan melalui jalur pendidikan, dan mengalami penyesuaian dengan kondisi dan situasi lingkungan yang dihadapi masing-masing.

\section{Kajian Literatur dan Pembahasan}

Selaras dengan pengertian pembangunan pada umumnya sebagai upaya perubahan, konsep pembangunan berkelanjutan mengacu pada perubahan suatu lingkungan fisik dan non-fisik secara berkesinambungan dengan mengoptimalkan dampak positif yang dihasilkan dan meminimalisir dampak negatifnya. Dalam konsep tersebut mencerminkan kepositifan hasil dan dampak yang ditimbulkan, dipertahankan, dirasakan manfaatnya, dan layak dijaga kesinambungannya oleh masyarakat penerimanya. Hal itu sesuai dengan teori dampak yang ditimbulkan dari suatu perubahan, bahwa suatu proses perubahan tidak hanya akan menimbulkan konsekuensi primer akibat langsung dari masuknya unsur baru, tetapi juga konsekuensi skunder yang searah dan memperkuat konsekuensi primer; selanjutnya konsekuensi skunder akan menimbulkan konsekuensi tersier yang searah dan memperkuat konsekuensi skunder; dan seterusnya.

Ibarat sebuah kolam air yang tenang, lalu dilemparkan sebutir batu ke dalamnya. Kolam tidak hanya menimbulkan lingkaran kecil akibat langsung lemparan batu, melainkan menimbulkan pula lingkaran-lingkaran lain yang semakin membesar. Dalam konteks ini, apabila pelaksanaan pembangunan nyata-nyata membawa perubahan ke arah yang positif dan bermanfaat, sudah menjadi kewajiban penerimanya untuk mempertahankan, menjaga, dan merawat keberhasilan dan kesinambungannya. Pertanyaan yang muncul: ke mana arah perubahan yang terjadi akibat dari penerapan suatu pembangunan? Apakah proses perubahan benar-benar mengarah pada optimalisasi dampak positifnya, dan sebaliknya meminimalisir dampak negatifnya; atau lebih mengarah pada kemunculan dampak negatif yang besar, sebaliknya memiliki hasil dan dampak positif yang relatif kecil.

Pelajaran menarik diperoleh dari pelaksanaan pembangunan masa lalu di daerah pedesaan di Indonesia, terutama pulau Jawa. Pengalaman berharga dari kasus itu memberikan pemahaman betapa pentingnya memberikan 
perhatian terhadap berbagai aspek kehidupan masyarakat penerimanya (resipien). Proses pembangunan yang ditujukan untuk meningkatkan kesejahteraan masyarakat desa dengan asumsi etnosentrisme barat, ternyata mengarah pada situasi sebaliknya, dan bahkan memunculkan permasalahan sosial baru. Foster (1973) mengemukakan, etnosentrisme barat beranggapan bahwa penerapan teknologi pembangunan yang pernah dijalankan di negara maju dan berhasil baik, maka akan memperlihatkan hasil yang baik pula apabila diterapkan ke dalam kehidupan masyarakat pedesaan di Indonesia. Melalui anggapan itu terjadi transfer teknologi modern traktor ke dalam kehidupan petani pedesaan guna meningkatkan produktivitas pertanian, dan dengan sendirinya dinilai dapat meningkatkan taraf hidup petani.

Sebagaimana lazimnya yang terjadi dalam proses perubahan, bahwa masuknya unsur baru akan mengakibatkan ketidakseimbangan dalam sistem semula dan memunculkan berbagai konsekuensi yang searah dan saling memperkuat. Konsekuensi primer dari penerapan teknologi modern berupa traktor pengolahan lahan pertanian ke wilayah pedesaan, nyata-nyata telah membawa ketidakseimbangan dalam sistem kehidupan semula. Teknologi traktor telah menggantikan tempat buruh tani maupun penggarap lahan pertanian dengan sistem upah maupun bagi hasil. Buruh tani dan penggarap kehilangan pekerjaan, dihadapkan dengan terbatasnya peluang kerja yang ada di pedesaan. Proses pembangunan untuk mensejahterakan hidup lebih menguntungkan sekelompok kecil petani pemilik lahan, sebaliknya kurang menyentuh sebagian besar masyarakat pedesaan. Kondisi involusi pertanian yang digambarkan Geertz (1963), di mana Buruh tani dan penggarap yang telah bergelut dengan tingkat kehidupan survival: sekedar melangsungkan kehidupan semakin diperparah dengan kehilangan sama sekali sumber pendapatan, yang lebih lanjut memerosokkan ke jurang kemiskinan yang lebih dalam lagi. Persoalan tidak berhenti di situ saja, tuntutan menghidupi keluarga mendorong terjadinya arus urbanisasi warga desa ke wilayah perkotaan untuk mencari pekerjaan. Tanpa dibekali dengan keahlian dan keterampilan memadai sesuai dengan kondisi dan kebutuhan perkotaan, arus urbanisasi telah memunculkan permasalahan sosial lainnya di wilayah ini berupa peningkatan jumlah penduduk miskin di kota, peningkatan jumlah pengangguran, peningkatan tindakan kriminalitas, dan sebagainya. Proses pembangunan yang dilancarkan tidak terbukti membawa dampak positif dalam kehidupan masyarakat pedesaan, dan bahkan memunculkan dampak negatif yang semakin membesar.

Kasus lain adalah upaya pengeksploatasian sumberdaya alam secara membabi buta dan tidak terkendali. Penebangan hutan tropis salah satunya, ternyata hanya menguntungkan segelintir orang, sebaliknya kurang dirasakan manfaatnya bagi peningkatan kesejahteraan hidup masyarakat secara meluas. Penebangan dan penggundulan hutan di berbagai wilayah di nusantara, bukan hanya telah merusak keseimbangan ekosistem sekitar, tetapi juga membawa dampak lainnya dalam kehidupan manusia, mulai dari musibah banjir, tanah longsor, pencemaran udara, sampai dengan perubahan iklim. Kasus lain adalah pengeksplorasian dan pengeksploatasian sumberdaya tambang dan mineral, kerapkali telah membawa dampak berupa gangguan dan kerusakan keseimbangan ekosistem sekitar, yang kemudian menimbulkan dampak dan ekses negatif lainnya.

\section{Perspektif Multidimensional}

Sejalan dengan upaya pembangunan yang dilaksanakan selama ini, masyarakat Indonesia mengalami berbagai perubahan dan perkembangan yang cukup pesat. Hasil dan dampak pelaksanaan pembangunan telah dirasakan oleh sebagian besar masyarakat, namun seiring dengan itu berbagai dampak negatif dan destruktif masih menjadi tantangan yang perlu ditanggulangi dalam pembangunan. Tantang yang ada mulai dari masih besarnya jumlah orang miskin yang belum terkena pembangunan dan memerlukan perhatian tersendiri, sampai dengan penanggulangan kerusakan lingkungan akibat ulah dan tindakan manusia berupa penggundulan hutan, pencemaran air dan udara, dan sebagainya. Meski demikian sejalan dengan keberhasilan pelaksanaan pembangunan selama ini, jelas memerlukan tindakan dan upaya mempertahankan, menjaga, dan merawat kesinambungannya. 
Sejak berdirinya pemerintahan orde baru tahun 1966 sampai dengan sekarang, dimensi ekonomi mendapat tekanan utama dalam pelaksanaan pembangunan nasional, dengan harapan keberhasilan dan kemajuan dalam dimensi ini akan mempengaruhi dan menyelimuti perbaikkan pula terhadap dimensi atau aspek kehidupan lainnya. Namun kerapkali prioritas pembangunan ekonomi mengorbankan dimensi kehidupan lainnya, sehingga bukan memunculkan hasil dan dampak positif sebagaimana diharapkan, melainkan sebaliknya. Atas dasar itu, pemikiran dan pelaksanaan pembangunan yang memberikan penekanan terhadap dimensi tertentu, perlu beralih dengan lebih memberikan perhatian atau perspektif dari berbagai dimensi. Dengan kata lain, pembangunan perlu dilaksanakan melalui perspektif multidimensional secara integratif, saling mempengaruhi, dan sinergis satu sama lain. Pelaksanaan pembangunan haruslah dilaksanakan secara komprehensif, serentak, dan meliputi berbagai dimensi aspek pembangunan, yakni: ekonomi, politik, hukum, kesehatan, dan sebagainya.

Pembangunan dalam lingkup keseluruhan maupun untuk setiap dimensi, mendukung tema, nilai dasar, dan tujuan yang ingin dicapai. Kenyataannya, pembangunan kerapkali tidak disertai dengan upaya penyebaran dan penanaman nilai dan tujuan kepada resipien. Bahkan, dalam penerapan suatu program sering tidak diketahui nilai dasar dan tujuan yang ingin dicapai, melainkan menjadi program dari segelintir

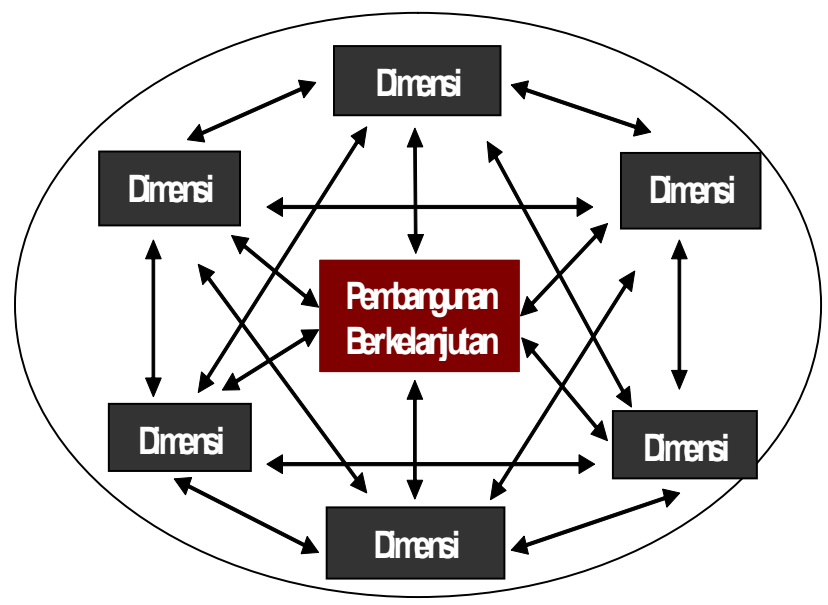

Bagan 1. Perspektif Multidimensional Pembangunan Berkelanjutan orang, yang sekaligus menguntungkan mereka. Pemberian Hak Penguasaan Hutan (HPH) misalnya, cenderung hanya menguntungkan dan memperkaya segelintir orang yang memperolehnya, sebaliknya kurang diketahui jelas dampak positif bagi masyarakat luas. Bahkan akibat dari pemberian $\mathrm{HPH}$ adalah penebangan dan penggundulan hutan secara membabi buta, yang pada akhirnya menimbulkan ekses negatif yang harus ditanggung dalam kehidupan masyarakat.

Upaya mempertahankan, menjaga, merawat, dan meningkatkan keberhasilan pembangunan dan kesinambungannya, baru akan terjadi apabila masyarakat penerimanya memahami, menyadari, dan memetik manfaat daripadanya. Oleh karena itu penerapan suatu pembangunan perlu disertai dengan penyebaran dan penanaman nilai dasar dan tujuan pembangunan itu sendiri, sehingga menimbulkan rasa memiliki (sense of belonging) penerimanya. Simak saja, kita tidak jarang mendapatkan dari lingkungan sekitar di mana pelaksanaan suatu pembangunan justru dirusak oleh sebagian orang yang tidak bertanggung jawab. Pembangunan untuk menata keindahan kota misalnya, justru menjadi kurang sedap dipandang karena dirusak oleh segelintir orang dengan mencorat-coret tembok, merusak fasilitas umum, dan sebagainya. Contoh lain adalah pembangunan jalan yang setiap tahun mengalami kerusakan dan perbaikkannya, akibat ulah segelintir oknum aparat yang membiarkan dilalui oleh kendaraan dengan beban melebihi kapasitas yang diperbolehkan. Ulah oknum aparat karena diberi imbalan sejumlah uang tertentu. Nilai dasar dan tujuan yang terkandung dalam pelaksanaan pembangunan jalan kurang dihayati dan dipahami secara mendalam, baik oleh pengguna maupun oknum aparat sendiri.

Contoh lain, dalam pembangunan politik bangsa Indonesia berkomitmen untuk mencapai suatu kehidupan civil society yang menunjung pluralisme dan demokrasi. Dalam karakteristik civil society setiap orang memiliki hak untuk berserikat dan berpendapat, yang dijamin pula oleh landasan konstitusi bangsa dan negara. Namun dalam kenyataannya, seringkali kemunculan aspirasi dan perbedaan pendapat bukan dicarikan melalui titik temu dialog di atas meja, melainkan dilakukan dengan cara demo terbuka disertai dengan 
tindakan pemaksaan kehendak dan anarkhis. Komitmen membangun kehidupan politik menuju masyarakat demokratis melalui prinsip kebebasan kurang disadari dan dipahami sepenuhnya melalui tindakan yang bertanggung jawab, melainkan cenderung kebablasan dan destruktif. Salah satu penyebab, pembangunan politik kerapkali tidak disertai dengan penyebaran dan penanaman secara meluas terhadap nilai dasar dan tujuan yang terkandung dalam konsepsi civil society.

Eksplisit, penerapan pembangunan mendukung tema, nilai dasar, dan tujuannya masingmasing. Manfaat dan kesinambungan keberhasilan pencapaian pelaksanaan pembangunan dapat terjamin apabila disertai dengan penyebaran dan penanaman nilai dasar dan tujuannya, sehingga memunculkan kesadaran, sikap, dan perilaku untuk mempertahankan, menjaga, merawat kesinambungan, dan bahkan meningkatkan keberhasilannya. Di sisi lain, kesadaran dan pemahaman akan memunculkan pula upaya untuk mengeliminir dampak negatif yang ditimbulkan. Persoalannya, bagaimana cara dan strategi yang perlu dijalankan guna menyebarkan dan menanamkan nilai dasar dan tujuan yang terkandung dalam penerapan suatu pembangunan? Sementara pihak beranggapan, pendidikan merupakan unsur potensial yang mampu berperan dalam upaya penyebaran dan penanaman nilai dasar dan tujuan pembangunan. Dalam tulisan ini, nilai dasar dan tujuan pembangunan merupakan bahan bagi penerapan Pendidikan Pembangunan Berkelanjutan (education development sustainable/ESD).

\section{Pendidikan Pembangunan Berkelanjutan}

\section{Makna Pendidikan}

Pendidikan merupakan satu istilah yang sering dilontarkan oleh berbagai pihak sebagai alat ampuh untuk melakukan perubahan terhadap kehidupan suatu masyarakat ke arah yang lebih baik. Bagi masyarakat yang kurang maju atau tertinggal dari masyarakat lainnya, pembangunan di bidang pendidikan merupakan upaya peningkatan kualitas sumber daya manusia yang diharapkan berdampak positif bagi peningkatan berbagai aspek kehidupan lainnya. Pembangunan pendidikan digunakan sebagai wahana proses transisi yang disengaja atau terencana agar berbagai segi kehidupan sistem sosial yang terkenanya dapat meningkat atau menjadi lebih baik.

Hal di atas sejalan dengan yang dikemukakan oleh Inkeles dan Smith (1974), "... bagaimanapun juga manusia bisa diubah secara mendasar setelah dia menjadi dewasa, dan karena itu tidak ada manusia yang tetap menjadi manusia tradisional dalam pandangan dan keperibadiannya hanya karena dia dibesarkan dalam sebuah masyarakat tradisional". Artinya, dengan suatu perencanaan dan implementasinya yang matang, cermat, dan tepat, setiap orang bisa diubah menjadi manusia modern. Lebih lanjut Inkeles dan Smith mengatakan, bahwa salah satu komponen yang langsung terkait dan memiliki andil besar dalam usaha meningkatkan kualitas sumber daya manusia adalah pendidikan dan pengajaran. Bahkan pendidikan memiliki dampak tiga kali lebih kuat dibanding usaha-usaha lainnya dalam membentuk kualitas sumber daya manusia yang tinggi, sehingga acapkali menjadi penentu bagi pencapaian kemajuan suatu bangsa dan peningkatan taraf hidup. Lalu, apa itu pendidikan?

Dalam ilmu antropologi, pendidikan diartikan sebagai proses belajar yang dijalani oleh seorang individu sepanjang hidupnya terhadap nilai-nilai, norma-norma, aturan-aturan yang didukung oleh lingkungan sosial di sekitarnya, sehingga menjadikannya sebagai pedoman bagi perwujudan tingkah laku individu yang bersangkutan. Pendidikan dalam pengertian ini lebih mengarah pada makna proses internalisasi dan sosialisasi yang dilakukan seorang individu terhadap nilainilai, norma, dan aturan dari lingkungan di sekitarnya, yang lebih lanjut menjadikannya sebagai bagian diri dan mekanisme kontrol bagi perwujudan perilaku. Melalui pendidikan, berlangsung proses pewarisan nilai, norma, aturan budaya yang didukung oleh suatu sistem sosial dari satu generasi ke generasi berikutnya.

Lain lagi dengan para pakar pendidikan penganut aliran eksistensialisme, melihat pengertian pendidikan dalam dua sudut, yakni arti luas dan arti sempit. Dalam arti luas, pendidikan merupakan segala kegiatan pembelajaran yang berlangsung sepanjang zaman dalam segenap situasi kegiatan kehidupan. Pendidikan berlangsung di semua jenis, bentuk, dan tingkat 
lingkungan hidup, yang kemudian mendorong pertumbuhan segala potensi yang ada di dalam diri individu. Singkatnya, pendidikan merupakan proses perubahan menuju pendewasaan, pencerdasan, dan pematangan diri individu. Dalam arti sempit, pendidikan dimaknai sebagai seluruh kegiatan belajar yang direncanakan, dengan materi terorganisasi, dilaksanakan secara terjadwal dalam sistem pengawasan, dan diberikan evaluasi berdasarkan pada tujuan yang telah ditentukan. Pendidikan dalam pengertian ini merupakan kegiatan belajar yang dilaksanakan di sekolah, dengan tujuan utama mengembangkan potensi intelektual dalam bentuk penguasaan bidang ilmu khusus dan kecakapan merakit sistem teknologi.

Bagi para pakar pendidikan pendukung aliran fungsionalisme dan kulturalisme melihat pendidikan dari sudut fungsinya, meski keduanya memiliki pandangan yang berbeda. Mereka yang mendukung pandangan fungsionalisme berpendapat, fungsi pendidikan sebagai transmisi kebudayaan dan mempertahankan tatanan sosial yang ada. Masa depan seorang individu dalam lingkungan sosialnya dipersiapkan dengan mengajarkan fungsi-fungsi dalam masyarakat. Bagi pendukung kulturalisme, fungsi pendidikan dilihat sebagai upaya untuk merekonstruksi masyarakat. Masyarakat mempunyai masalah-masalah yang dihadapi dan upaya pendidikan ialah untuk mengatasi masalah-masalah tersebut seperti identitas bangsa, benturan kebudayaan, preservasi dan pengembangan budaya (Tilaar, 2004).

Suatu aliran yang populer akhir-akhir ini adalah pasca-modern yang memandang fungsi pendidikan masa kini merupakan upaya transmisi ilmu pengetahuan dan tekonologi, sedangkan masyarakat masa depan perlu menghargai kemajemukan dan keragaman pendapat. Fungsi pendidikan adalah membina pribadi-pribadi yang bebas merumuskan pendapat dan menyatakan pendapat sendiri dalam berbagai perspektif. Individu yang diinginkan adalah individu yang kreatif dan berpikir bebas termasuk berpikir produktif. Pandangan pasca-modern menitikberatkan pada pemberdayaan individu, namun kebebasan atau otonomi individu bukanlah tanpa batas melainkan tetap dalam koridor menjaga keseimbangan tatanan sosial di sekitar yang terkait dengan nilai-nilai inti (core values) yang didukung bersama.

Bagaimana dengan Indonesia? Secara legalistik konsepsi pendidikan merupakan bagian integral dalam penyelenggaraan sistem pendidikan nasional yang diatur melalui UndangUndang Nomor 20 Tahun 2003. Pengertian pendidikan dalam undang-undang tersebut ditegaskan sebagai "usaha sadar dan terencana untuk mewujudkan suasana belajar dan proses pembelajaran agar peserta didik secara aktif mengembangkan potensi dirinya untuk memiliki kekuatan spritual keagamaan, pengendalian diri, keperibadian, kecerdasan, akhlak mulia, serta keterampilan yang diperlukan dirinya, masyarakat, bangsa, dan negara" (pasal 1:1).

Inti dari berbagai pengertian di atas, bahwa pendidikan merupakan upaya penyebaran dan penanaman nilai. Dalam konteks penyelenggaraan sistem pendidikan nasional, pendidikan merupakan suatu upaya perubahan terencana atau disengaja untuk mencapai tujuan tertentu. Melalui nilai yang terkandung dalam pendidikan bukan hanya merupakan suatu upaya untuk meningkatkan kualitas sumberdaya manusia, tetapi juga diharapkan dapat membuka cakrawala pengetahuan, kesadaran, dan pemahaman mengenai diri maupun lingkungan di sekitarnya, sehingga dapat bermanfaat dalam melakukan perubahan kehidupan ke arah yang lebih baik.

\section{Konsep dan Operasionalisasi}

Pendekatan multidimensional menyiratkan, bahwa pelaksanaan pembangunan nasional mengandung sejumlah komponen pembangunan, yakni pembangunan ekonomi, politik, sosial, kesehatan, pendidikan, dan lain-lainnya. Setiap komponen mengandung tema-tema yang berisikan nilai dasar dan tujuan suatu pembangunan dilaksanakan. Dengan demikian, apabila nilai dasar dan tujuan ingin disebarluaskan dan ditanamkan melalui jalur pendidikan, perlu dijabarkan ke dalam kompetensi dan deskripsi pembelajaran agar dapat menjadi pedoman atau acuan bagi pihak terkait dalam upaya penerapan dalam pembelajaran. Skema pendidikan pembangunan berkelanjutan melalui pendekatan multidimensional, komponen, sampai dengan penerapannya dalam jalur pendidikan digambarkan dalam bagan 
1 di bawah. Kemudian dalam tulisan dikemukakan contoh perspektif multidimensional pembangunan berkelanjutan yang terbagi dalam komponen, tema, kompetensi, dan deskripsi singkat pembelajaran. Keseluruhan ini masih memerlukan penjabaran lebih lanjut dengan melibatkan para ahli di bidang masing-masing, agar dapat digunakan sebagai acuan dalam penerapannya melalui pendidikan.

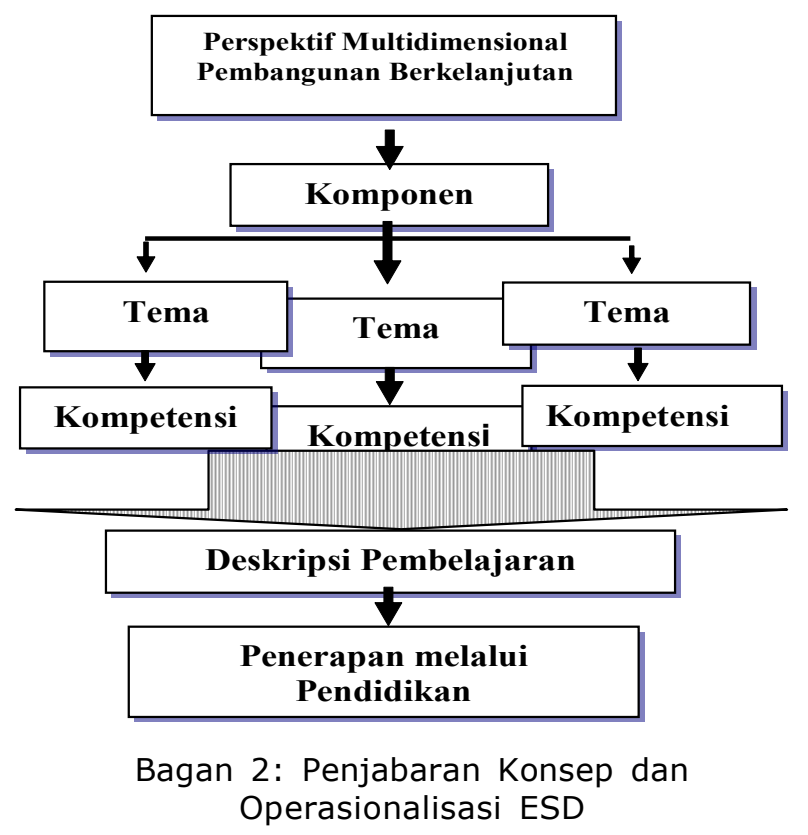

\section{Penerapan Pendidikan Pembangunan Berkelanjutan Dalam Satuan Pendidikan}

Pendidikan merupakan usaha terencana untuk mengembangkan kecerdasan peserta didik, yakni kecerdasan intelektual, spiritual, emosional, sosial, dan kinestis. Untuk itu sistem pendidikan nasional dilaksanakan secara berjenjang melalui 3 (tiga) jalur, yakni formal, nonformal, dan informal. Jalur formal merupakan jalur yang berstruktur dan berjenjang yang terdiri atas dasar, menengah, dan tinggi. Jalur informal merupakan jalur keluarga dan lingkungan, sedangkan jalur non-formal merupakan jalur di luar formal yang dapat dilaksanakan secara berstruktur dan berjenjang. Kegiatan di satuan pendidikan dapat dibedakan ke dalam 2 (dua) jenis kegiatan, yakni pembelajaran intrakurikuler dan ekstrakurikuler.

ESD berisikan seperangkat nilai dasar dan tujuan dari pelaksanaan pembangunan yang multidimensional sifatnya. Melalui pendidikan diharapkan dapat menimbulkan kesadaran dan pemahaman masyarakat penerima akan arti penting pembangunan dilaksanakan dan hasil yang dicapai bagi perbaikkan hidup, sehingga mampu mempertahankan, menjaga, dan merawat kesinambungannya. Dalam konteks penyelenggaraan pendidikan melalui satuan pendidikan, penyebaran dan penanaman nilai dasar dan tujuan pembangunan melalui pendidikan, secara sederhana digambarkan dalam bagan 2 di bawah ini.

Penyebaran dan penanaman nilai dasar dan tujuan pembangunan berkelanjutan melalui pendidikan atau ESD tidak terlepas dari pentingnya dukungan instansi di tingkat pusat, provinsi, dan daerah. Di tingkat pusat dukungan tersebut terkait dengan kebijakan dan program, bantuan fasilitas, dana, sampai dengan pemantauan, pengawasan, dan penilaian hasil yang dicapai. Dalam upaya pendalaman dan penerapan konsep ESD pun amat diperlukan adanya kerjasama dengan berbagai pihak yang terkait, seperti pengelola pramuka tingkat pusat dan daerah (kwartir nasional dan kwartir daerah), lembaga-lembaga pengelola seni budaya, pusatpusat kebugaran, dan sebagainya. Masingmasing pihak memiliki peran yang perlu disesuaikan dan terintegrasi ke dalam tugas pokok dan fungsi instansi/lembaga.

Segenap hal di atas melingkupi perspektif multimensional pembangunan berkelanjutan, komponen, tema, kompetensi, dan deskripsi pembelajaran. Substansi/materi ESD merupakan masukan bagi satuan pendidikan untuk menyebarkan dan menanamkannya ke peserta didik. Untuk itu sebaiknya dibentuk Tim Pengembang ESD (tingkat kabupaten untuk intrakurikuler, dan satuan pendidikan untuk ektrakurikuler) dengan tugas dan fungsi mensosialisasikan kepada guru, pembina/ pembimbing ekstrakurikuler; mencari, memenuhi, dan mendukung fasilitas dan pendanaan yang dibutuhkan; melakukan pemantauan dan pengawasan; dan lain-lainnya.

ESD di satuan pendidikan dilakukan dengan cara mengintegrasikan ke dalam kegiatan intrakurikuler (mata pelajaran) dan ekstrakurikuler (kepramukaan, seni-budaya, dan lain-lainnya). Meski dalam jalur pendidikan, ESD merupakan materi tumpangan untuk membangun kesadaran, pemahaman, dan perubahan sikap dan perilaku 
Tabel 1. Contoh Matriks Penerapan Pembangunan Berkelanjutan Melalui Pendidikan

\begin{tabular}{|c|c|c|c|c|c|}
\hline No. & $\begin{array}{c}\text { Dimen } \\
\text {-si } \\
\text { Pem } \\
\text { ba } \\
\text { ngun } \\
\text { an }\end{array}$ & $\begin{array}{l}\text { Kompo- } \\
\text { nen }\end{array}$ & $\begin{array}{c}\text { Tema (Nilai } \\
\text { Dasar dan } \\
\text { Tujuan) }\end{array}$ & Kompetensi & Deskripsi Singkat Pembelajaran \\
\hline 1. & Politik & $\begin{array}{l}\text { 1. Sis- } \\
\text { tem } \\
\text { Pemi- } \\
\text { lihan } \\
\text { Umum }\end{array}$ & $\begin{array}{l}\text { Memahami penye } \\
\text { lenggaraan peme } \\
\text { rintahan dengan } \\
\text { jiwa dan sema } \\
\text { ngat otonomi dae } \\
\text { rah yang membe } \\
\text { rikan kewenangan } \\
\text { dan keleluasaan } \\
\text { kepada pemerin } \\
\text { tah kab/ kota } \\
\text { untuk mengelola } \\
\text { segenap aspek } \\
\text { pem bangunan } \\
\text { diwilayahnya. } \\
\text { Memahami mak } \\
\text { na kemajemukan } \\
\text { (plural) dalam ke } \\
\text { hidupan masyara } \\
\text { kat Indonesia ber } \\
\text { dasarkan ras, a } \\
\text { gama, suku bang } \\
\text { sa, dan sebagai } \\
\text { nya, dan penting } \\
\text { nya mem bangun } \\
\text { persatuan-kesa } \\
\text { tuan dan kebersa } \\
\text { maan dari kema } \\
\text { jemukan tsb. }\end{array}$ & $\begin{array}{l}\text { Peserta didik dapat } \\
\text { memahami penting } \\
\text { nya penyelenggaraan } \\
\text { pemilihan umum se } \\
\text { bagai pengeja wantah } \\
\text { an kedaulatan di } \\
\text { tangan rakyat, yang } \\
\text { dilaksanakan melalui } \\
\text { pemilihan umum de } \\
\text { ngan asas langsung, } \\
\text { bebas, dan rahasia. } \\
\\
\text { Peserta didik dapat } \\
\text { memahami bentuk } \\
\text { pemerintahan otonomi } \\
\text { daerah yang di landasi } \\
\text { dengan jiwa dan sema } \\
\text { ngat demokratis, keter } \\
\text { bukaan, dan akunta } \\
\text { bilitas publik, serta } \\
\text { pentingnya keterlibat } \\
\text { an dan partisipasi ma } \\
\text { syarakat ke dalam pe } \\
\text { ngelolaan segenap } \\
\text { aspek pembangun an } \\
\text { daerah. } \\
\text { Peserta didik dapat } \\
\text { memahami makna } \\
\text { kemajemukan seba } \\
\text { gai potensi dan ke } \\
\text { kayaan bangsa, di } \\
\text { jamin dalam konsti } \\
\text { tusi, dan memerlu kan } \\
\text { sikap toleransi, } \\
\text { solidaritas, saling } \\
\text { menghormati, saling } \\
\text { menghargai, dan lain- } \\
\text { lainnya. } \\
\end{array}$ & $\begin{array}{l}\text { Landasan konstitusional bangsa dan negara me } \\
\text { negaskan bahwa kedaulatan berada di tangan } \\
\text { rakyat, yang dilakukan melalui pemilihan umum } \\
\text { secara langsung, bebas, danrahasia untuk me } \\
\text { milih wakil-wakil rakyat yang akan duduk di lem } \\
\text { baga legislatif tingkat pusat, provin si, dan kab/ } \\
\text { kota, serta presiden dan wakil presiden. Pemilu } \\
\text { dilaksanakan sekali dalam lima tahun, dengan } \\
\text { diikuti oleh kontestan partai politik yang telah } \\
\text { mendapat verifikasi dan pengesahan dari lemba } \\
\text { ga pemilihan umum. Partisipasi rakyat dalam } \\
\text { pemilu menja di penting untuk memberikan } \\
\text { legiti masi yang kuat terhadap calon yang } \\
\text { berhasil dipilih. } \\
\text { Berdasarkan UU No. } 32 \text { Th } 2005 \text { tentang } \\
\text { Pemerintahan Daerah, daerah diberikan kewe } \\
\text { nangan dan keleluasaan dalam mengelola } \\
\text { segenap aspek pembangunan di wilayahnya, } \\
\text { kecuali terhadap aspek tertentu yang masih } \\
\text { menjadi kewenangan pusat dalam pengelola } \\
\text { annya (Pertahanan, Keaman an, Agama, } \\
\text { Keuangan, dan Fiskal). Penyelenggaraan pe } \\
\text { merin tahan di daerah dilandasi oleh jiwa dan } \\
\text { semangat demkoratis, keterbukaan, dan } \\
\text { akuntabilitas publik, sehingga menuntut } \\
\text { kesadaran dan pemahaman segenap lapisan } \\
\text { masyarakat di daerah untuk mendukung } \\
\text { pengelolaan dan keberhasilannya. } \\
\text { Pluralisme merupakan nilai yang harus ada } \\
\text { dalam karakteristik masyarakat modern. } \\
\text { Pluralisme harus dipahami sebagai potensi dan } \\
\text { kekayaan bangsa melalui kehidupan yang salins } \\
\text { menghargai dan menerima kemajemukan dan } \\
\text { perbedaan dengan sikap dan bernilai positif. } \\
\text { Bahkan, pluralisme merupakan suatu keharusar } \\
\text { bagi keselamatan umat manusia, antara lain } \\
\text { dengan melalui mekanisme chek dan balance. }\end{array}$ \\
\hline & & $\begin{array}{l}\text { 4.Demo- } \\
\text { krati- } \\
\text { sasi }\end{array}$ & $\begin{array}{l}\text { Memahami } \\
\text { tentang makna } \\
\text { dan nilai } \\
\text { kebebasan } \\
\text { dalam berserikat } \\
\text { dan } \\
\text { berpendapat. }\end{array}$ & $\begin{array}{l}\text { Peserta didik dapat } \\
\text { memahami makna } \\
\text { tentang demokratisasi } \\
\text { yang dijamin oleh } \\
\text { konstitusi, baik dalam } \\
\text { hal berserikat dan } \\
\text { berpendapat secara } \\
\text { bertanggung jawab. }\end{array}$ & $\begin{array}{l}\text { Warisan budaya feodalisme dan paternalisme } \\
\text { yang masih kental didukung oleh masyarakat } \\
\text { Indonesia tidak sesuai dengan jiwa dan sema } \\
\text { ngat civil society, sehingga perlu dirubah melalu } \\
\text { upaya penumbuhan kesadaran dan pemahamal } \\
\text { makna demokratis dalam konteks ba ngunan } \\
\text { kehidupan civil society. Eksplisit, demo krasi } \\
\text { merupakan prasyarat nilai utama dalam civil } \\
\text { society. Dengan demokrasi dimaksudkan } \\
\text { kedaulatan di tangan rakyat, dan kehidupan } \\
\text { berbangsa dan bernegara diselenggarakan } \\
\text { melalui perwakilan yang diperoleh secara } \\
\text { langsung, bebas, dan rahasia. Demokrasi juga } \\
\text { bermakna sebagai kebebasan berserikat dan } \\
\text { berpendapat. Perbedaan yang ada merupakan } \\
\text { rakhmat yang harus dicarikan titik temunya } \\
\text { melalui cara-cara elegan, perundingan, dan } \\
\text { menguntungkan satu sama lain. Bukan melalui } \\
\text { cara-cara penekanan, mementingkan diri atau } \\
\text { kelompoknya, dan mewujudkan sikap dan } \\
\text { perilaku anarkhis dan destruktif. }\end{array}$ \\
\hline 2. & $\begin{array}{l}\text { Ekono } \\
\mathrm{mi}\end{array}$ & $\begin{array}{l}\text { Dan sete } \\
\text { rusnya }\end{array}$ & Dan seterusnya & Dan seterusnya & Dan seterusnya \\
\hline
\end{tabular}




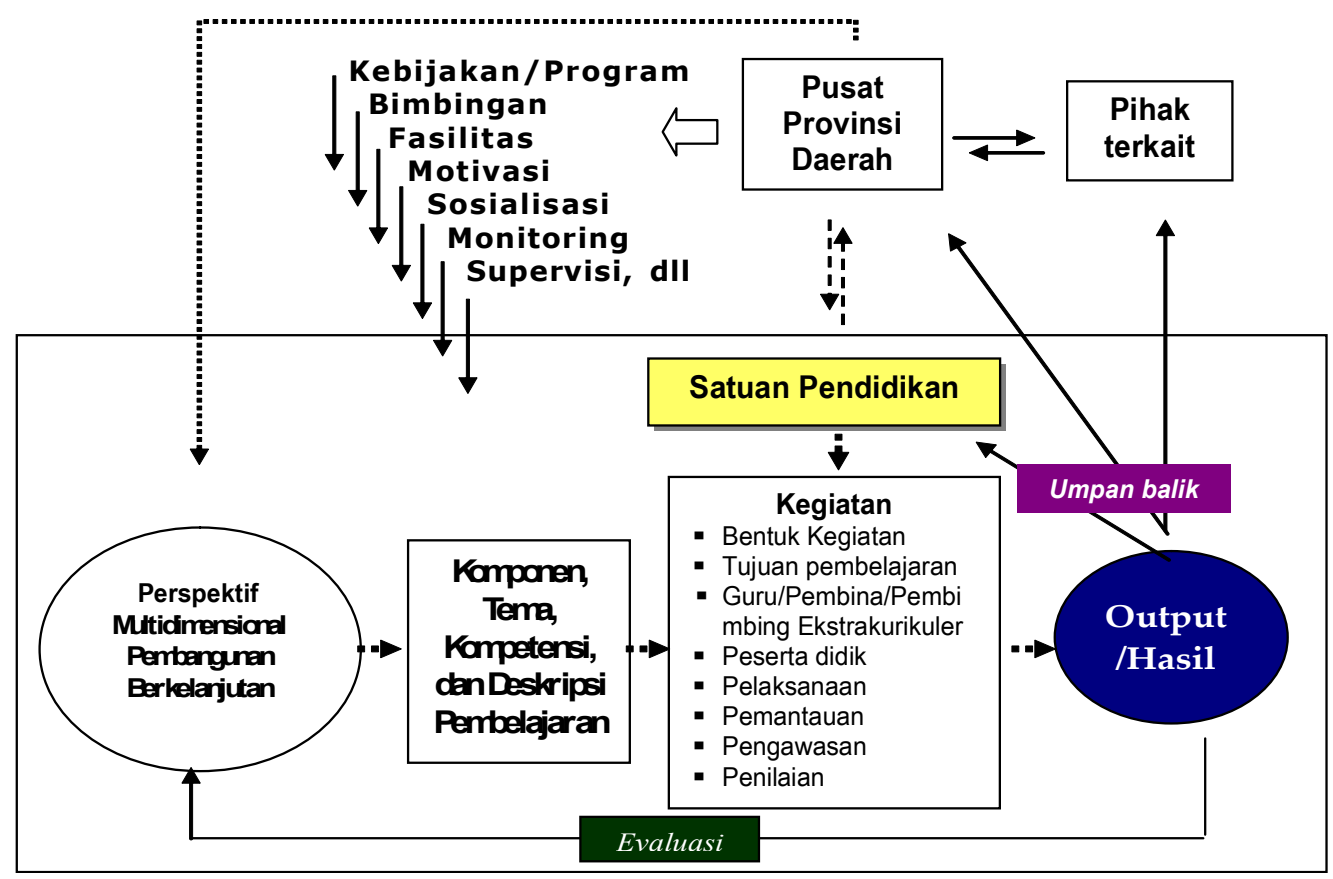

Bagan 3: Kerangka Berpikir Penerapan ESD Melalui Pendidikan

Keterangan :

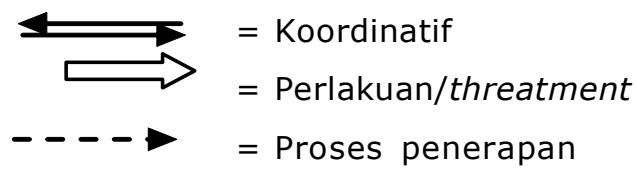

yang selaras dengan konsep pembangunan berkelanjutan, namun sebaiknya dilakukan evaluasi untuk mengetahui keberhasilan penerapannya. Hasil penilaian menjadi umpan balik (feedback) bagi satuan pendidikan dan pihakpihak lainnya yang terkait, terutama untuk mengetahui kekurangan, kelemahan, dan perbaikkan yang diperlukan dalam penerapan selanjutnya.

\section{Penerapan Melalui Intrakurikuler \\ Peran Guru dalam Penerapan ESD}

Permasalahan yang masih dihadapi dalam penyelenggaraan pendidikan nasional adalah berlangsungnya disparitas mutu pendidikan yang cukup menyolok antardaerah dan antarsekolah. Berbagai faktor diduga menjadi penyebab disparitas pencapaian mutu tersebut, salah satunya adalah perbedaan kemampuan guru. Hasil pengamatan penulis di sejumlah sekolah menunjukkan, bahwa terdapat perbedaan dari berbagai aspek yang berlangsung antarsekolah.
Satu sekolah memperlihatkan kinerja guru yang tinggi, antara lain ditunjukkan melalui suasana pembelajaran yang aktif dan bergairah; penggunaan metode/teknik mengajar yang variatif; pemanfaatan berbagai sumber dan media belajar dalam kegiatan pembelajaran; keaktifan guru dalam kelompok kerja guru, dan sebagainya. Sebaliknya sekolah yang lain memperlihatkan kinerja guru yang rendah yang ditunjukkan melalui perilaku pembelajaran yang cenderung pasif dan kurang bergairah, bergelut dengan rutinitas kerja, miskin kreatif dalam mencari sumber pengayaan materi pembelajaran, penggunaan metode/teknik mengajar yang kurang variatif, motivasi dan aktivitas wadah kelompok kerja guru yang rendah, dan sebagainya.

Seiring dengan itu, perbedaan juga diperlihatkan dalam sejumlah aspek lainnya yang searah dan memperkuat kinerja guru di kedua kategori sekolah. Sekolah dengan kinerja guru yang tinggi mencerminkan tingkat kepuasan kerja (job satisfaction) guru yang tinggi, sebaliknya sekolah dengan kinerja guru yang rendah memperlihat- 
kan tingkat kepuasan kerja yang rendah. Perbedaan lain adalah keaktifan dan kedinamisan wadah kelompok kerja guru dari kedua kategori sekolah tersebut. Di sekolah dengan kinerja guru yang tinggi cenderung memperlihatkan keaktifan dan kedinamisan yang tinggi pula terhadap wadah kelompok kerja guru, sehingga wadah ini dapat berfungsi sebagai wahana pertukaran (sharing) pengalaman, pembelajaran, dan pemecahan masalah terkait dengan pelaksanaan tugas mengajar secara bersama. Sebaliknya di sekolah dengan kinerja guru yang rendah, wadah kelompok kerja guru cenderung kurang aktif, dan kurang berfungsi sebagaimana mestinya.

Peran guru amat strategis apabila dikaitkan dengan upaya meningkatkan kulitas sumberdaya manusia Indonesia yang memiliki kualitas dan daya saing tinggi. Dalam menghadapi situasi global, penguasaan ilmu pengetahuan dan teknologi informasi mutakhir menjadi makin penting sebagai mesin pertumbuhan (engine of growth). Dengan kata lain, guru dapat menjadi pintu masuk dalam upaya meningkatkan sumberdaya manusia Indonesia yang berkualitas dan memiliki daya saing tinggi, agar dapat memetik manfaat dari situasi global guna meningkatkan taraf hidup masyarakat kita. Simak saja pengalaman sejumlah negara di sekitar kita, meski mereka miskin akan potensi sumberdaya alam, tetapi memiliki sumberdaya manusia yang berkualitas tinggi, ternyata mampu mencapai kesejahteraan hidup masyarakatnya. Implisit, sumberdaya manusia yang berkualitas tinggi menuntut kualitas hasil pendidikan yang tinggi pula. Untuk itu mutlak diperlukan adanya guru dan tenaga pendidikan yang bukan hanya memenuhi akademik yang dipersyaratkan, tetapi juga pengetahuan dan kemampuan mengajar yang memadai. Dalam pembahasan yang terakhir itu, upaya meningkatkan pengetahuan dan kemampuan guru perlu dijalankan secara intensif, berkesinambungan, dan efektif.

\section{Potensial Wadah KKG/MGMP dalam Penerapan ESD}

Salah satu upaya pembinaan yang sudah sejak lama dilaksanakan oleh pemerintah, adalah melalui pembentukan wadah Kelompok Kegiatan Guru (KKG) dan Musyawarah Guru Mata Pelajaran
(MGMP). Wadah KKG/MGMP yang mendukung prinsip dari, oleh, dan untuk guru diharapkan dapat menjadi entry point dalam meningkatkan pengetahuan dan kemampuan guru melaksanakan tugas dan fungsi utamanya. Wadah KKG/MGMP merupakan kelanjutan dari pelatihan kerja guru (PKG) yang dilaksanakan sebelumnya, dengan tujuan mampu mempertahankan pencapaian hasil dan pengimbasan terhadap guru lain yang belum menerima pelatihan ini. Wadah ini berfungsi ganda, selain merupakan tempat berkumpul bagi guru untuk membahas dan memecahkan permasalahan yang berhubungan dengan tugas mengajarnya secara bersama, juga sebagai upaya pengimbasan pengetahuan dan kemampuan dari guru yang satu ke guru yang lainnya. Keberadaan KKG dan MGMP didesain untuk mendukung peningkatan kemampuan guru, yang pada akhirnya diharapkan berpengaruh positif terhadap pencapaian visi, misi dan tujuan pendidikan nasional. Aktivitas yang dilaksanakan KKG dan MGMP sangat bervariasi, mulai dari penyiapan silabus implementatif, bahan ajar, metode, penilaian proses dan hasil belajar, lembar kerja, dan pengembangan alat peraga.

Pemberdayaan KKG/MGMP diharapkan merupakan satu langkah dalam penjaminan mutu pendidikan, melalui kemampuan peran dan fungsinya sebagai forum antar guru berbagi (share) pengalaman dan mencari alternatif solusi dalam pembelajaran. Implisit, pemberdayaan wadah KKG/MGMP mencerminkan upaya pemberdayaan diri untuk mewujudkan pelaksanaan fungsi dan tugasnya sebagaimana diharapkan, yang pada akhirnya bermuara pada pencapaian hasil pendidikan yang memuaskan. Pemberdayaan merupakan proses mengembangkan kompetensi dengan pertumbuhan dirinya dan menyelesaikan sendiri masalah yang dihadapinya. Tulisan ini tidaklah bermaksud membahas, apakah KKG/MGMP telah menunjukkan kemampuan dan pemberdayaannya sebagaimana yang diharapkan atau sebaliknya? Terlepas dari keseluruhan itu, dalam konteks penerapan ESD, pada dasarnya wadah KKG/MGMP memiliki potensi dan peran penting dalam meningkatkan pengetahuan dan kemampuan guru, serta penyebaran dan penanaman nilai ESD kepada peserta didik. Oleh karena itu, upaya penerapan ESD melalui bidang pendidikan pun mengarahkan perhatian dan 
pendekatannya terhadap peran KKG/MGMP dengan mengintegrasikan ke dalam kegiatan intrakurikuler dan ekstrakurikuler.

\section{Penerapan ESD melalui Intrakurikuler}

Sebagai wadah peningkatan pengetahuan, penguasaan, kemampuan dan keterampilan dalam menjalankan tugas utamanya, tidak berlebihan apabila upaya penyebaran nilai dasar dan tujuan pembangunan berkelanjutan atau ESD melalui intrakurikuler melirik terhadap potensi dan peran KKG/MGMP. Wadah KKG/MGMP dapat dijadikan wahana untuk menyebarkan dan menanamkan nilai dasar dan tujuan pelaksanaan pembangunan dengan mengintegrasikan ke dalam kegiatan intrakurikuler. KKG/MGMP dapat menjadi mediator dalam upaya penyebarluasan dan penanaman nilai dasar dan tujuan pembangunan. Untuk mendukung pemberdayaan KKG/MGMP Kabupaten/ Kota, hendaknya dapat dibentuk suatu kelompok kerja atau tim pengembang yang bertugas khusus untuk mensosialisasikan, membimbing, dan membantu guru dalam wadah KKG/MGMP mengintegrasikan nilai dan tujuan ESD ke dalam mata pelajaran. Untuk itu Tim Pengembang dapat bekerjasama dengan pihak lainnya (narasumber/ pakar/tokoh masyarakat, dan lainnya) guna pendalaman materi sebagai bahan mengintegrasikan ke dalam mata pelajaran yang relevan. Untuk selanjutnya guru menggunakan sebagai bahan ajar dalam menjalankan proses pembelajaran kepada peserta didiknya.

Tugas lain yang dimiliki oleh Tim Pengembang adalah melakukan pemantauan secara rutin

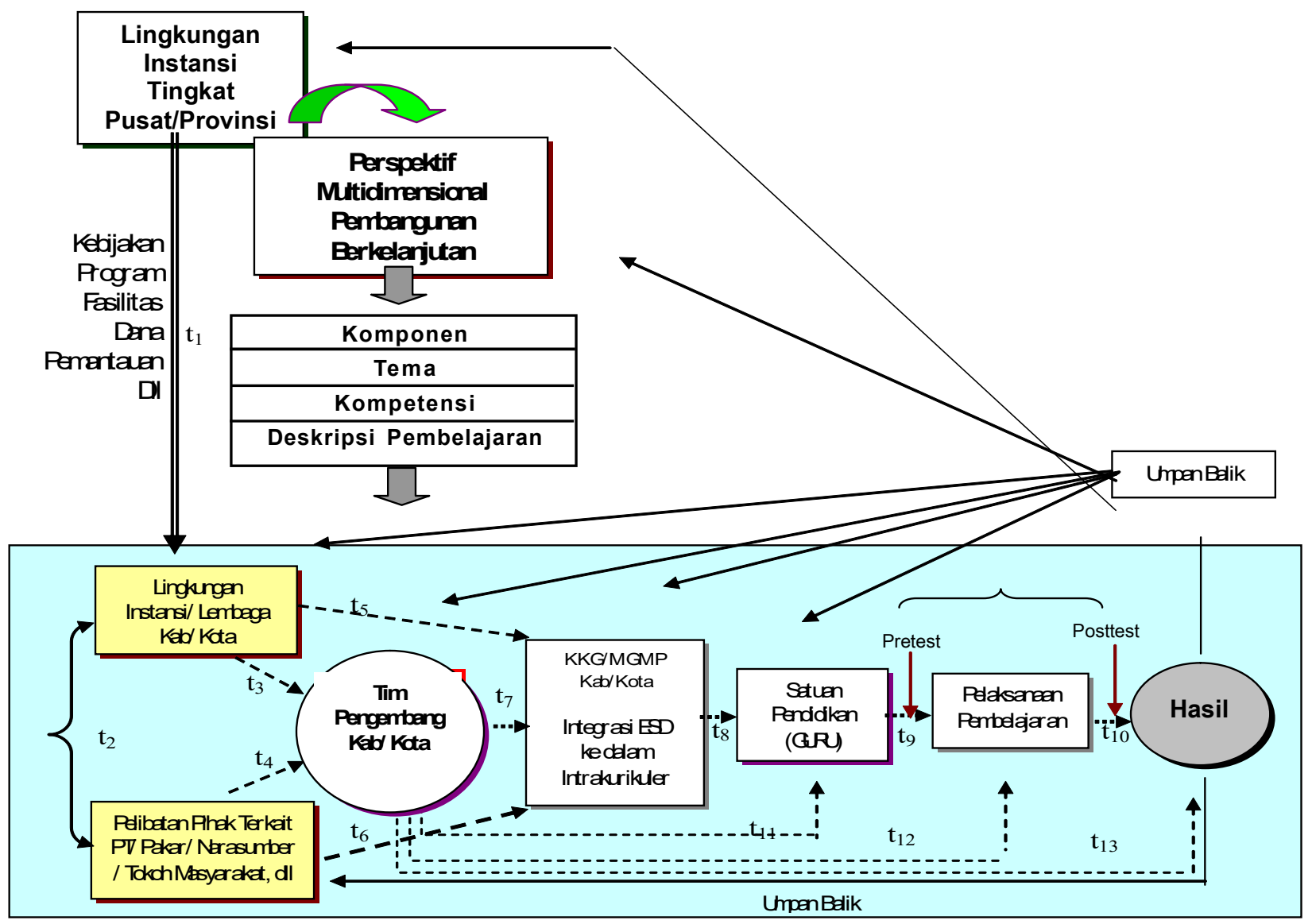

Tingkat Kabupaten/Kota dan Sekolah

Bagan 4. Model Intrakurikuler dalam Penerapan ESD

Keterangan:

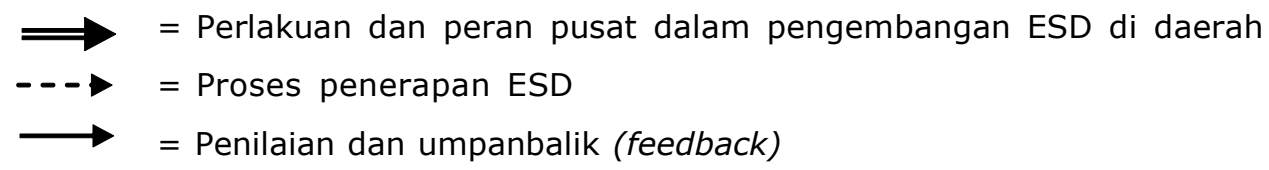


maupun berkala terhadap proses pembelajaran oleh guru. Sebelum pembelajaran dimulai, sebaiknya Tim Pengembang memberikan pretest terlebih dahulu untuk mengetahui kondisi awal pengetahuan dan pemahaman peserta didik terhadap ESD. Posttest dilakukan setelah proses pembelajaran diberikan kepada peserta didik selama kurun waktu tertentu, untuk mengetahui dan menilai keefektifan penyebaran ESD. Hasil posttest dapat digunakan sebagai umpanbalik (feedback) bagi instasi/lembaga terkait, tim pengembang, guru, maupun sekolah sendiri, untuk melakukan perbaikkan dalam penerapannya lebih lanjut.

Di bawah ini ditampilkan kerangka berpikir penerapan ESD dalam kegiatan intrakurikuler dengan melibatkan pendekatan terhadap peran KKG/MGMP.

\section{Penjelasan Bagan 3:}

Threatment $1\left(t_{1}\right)$, yaitu: 1$)$ Instansi pusat dan provinsi melakukan koordinasi dengan pihak terkait untuk menentukan program terkait dengan ESD; 2) Instansi pusat dan provinsi mengeluarkan kebijakan, program, dan pedoman materi/ substansi ESD; 3) Instansi pusat dan provinsi mendorong penerapan ESD, dengan memberikan bantuan fasilitas, dana, dan sebagainya yang diperlukan; 4) Mensosialisasikan kebijakan dan perangkat lain yang menyertainya ke daerah (kabupaten/kota).

Threatment $2\left(t_{2}\right)$, yaitu: 1) Pemerintah daerah mengeluarkan kebijakan penerapan ESD di satuan pendidikan; 2) Mensosialisasikan ESD secara meluas ke satuan pendidikan dan guru; dan 3) Berkoordinasi dengan berbagai pihak terkait (narasumber, pakar, tokoh masyarakat, dan lain-lainnya) guna pendalaman materi ESD.

Threatment $3\left(t_{3}\right)$, yaitu: 1$)$ Membentuk kelompok kerja atau Tim Pengembang yang bertugas mengembangkan dan merumuskan ESD dan 2) Membantu fasilitas, pendanaan, buku referensi, pedoman ESD, dan lain-lainnya terkait pensosialisasian dan pelaksanaan kegiatan tim pengembang dalam penerapan ESD.

Threatment $4\left(t_{4}\right)$ yaitu: Kerjasama dan bantuan pendalaman ESD dari narasumber, pakar, tokoh masyarakat, dan lainnya kepada Tim Pengembang.
Threatment $5\left(t_{5}\right)$, yaitu: 1) Penerbitan kebijakan bagi penerapan ESD melalui peran dan fungsi KKG/MGMP dan 2) Membantu fasilitas, pendanaan, buku referensi, pedoman ESD, dan lain-lainnya terkait pensosialisasian dan penerapan ESD kepada KKG/MGMP.

Threatment $6\left(\mathrm{t}_{6}\right)$ yaitu: Bantuan pendalaman ESD dari narasumber, pakar, tokoh masyarakat, dan lainnya kepada KKG/MGMP.

Threatment $7\left(t_{7}\right)$, yaitu: 1) Tim Pengembang mensosialisasikan ESD ke KKG/MGMP dan 2) Tim Pengembang bertugas memandu/membimbing/ membantu guru mengintegrasikan ke mata pelajaran.

Threatment $8\left(\mathrm{t}_{8}\right)$ yaitu: 1) Guru dalam wadah KKG/MGMP mengintegrasikan nilai ESD ke dalam materi mata pelajaran yang menjadi tugas utama mengajar; 2) Guru merancang pembelajaran, termasuk materi ESD.

Threatment $9\left(t_{9}\right)$ yaitu: 1 ) Tim Pengembang melaksanakan pretest; 2) Melakukan pengolahan data hasil pretest.

Threatment $10\left(t_{10}\right)$ yaitu: 1) Tim Pengembang melaksanakan posttest; 2) Melakukan pengolahan data hasil posttest.

Threatment $11\left(t_{11}\right)$ yaitu: 1) Tim Pengembang memberikan bantuan yang diperlukan guru dalam merancang pembelajaran dan mengintegrasikan ke dalam materi pembelajaran; 2) Tim Pengembang memberikan bantuan fasilitas terkait pembelajaran ESD.

Threatment $12\left(t_{12}\right)$ yaitu: 1) Tim Pengembang melakukan pemantauan pembelajaran ESD secara rutin maupun berkala; 2) Menyusun laporan hasil pemantauan.

Threatment $13\left(t_{13}\right)$ yaitu: 1$)$ Tim Pengembang melakukan evaluasi pembelajaran ESD secara rutin maupun berkala; 2) Menyusun laporan hasil evaluasi; 3) Melakukan perbaikkan pelaksanaan tugas, dan menentukan tindak lanjut penerapan ESD.

\section{Penerapan ESD Melalui Ekstrakurikuler}

Sama halnya dengan intrakurikuler yang dibicarakan di atas, penerapan ESD melalui ekstrakurikuler pun dilakukan dengan cara mengitegrasikan ke dalam kegiatan tersebut. Dalam intrakurikuler, nilai-nilai ESD diintegrasikan 
dan menjadi bagian dalam mata pelajaran, sedangkan dalam ekstrakurikuler diintegrasikan ke dalam jenis kegiatan yang relevan. Namun apabila dalam intrakurikuler melibatkan pendekatannya terhadap peran KKG/MGMP di tingkat kabupaten/kota, penerapan ESD melalui kegiatan ekstrakurikuler lebih mengarahkan perhatian ke tingkat satuan pendidikan. Di bawah ini selanjutya dikemukakan suatu alternatif pengembangan model penerapan ESD melalui ekstrakurikuler.

Kegiatan Ekstrakurikuler merupakan salah satu komponen dari kegiatan pengembangan diri yang terprogram. Artinya kegiatan tersebut direncanakan secara khusus dan diikuti oleh peserta didik sesuai dengan kebutuhan dan kondisi pribadinya. Kegiatan Ekstrakurikuler adalah kegiatan pendidikan di luar mata pelajaran dan pelayanan konseling untuk membantu pengembangan peserta didik sesuai dengan kebutuhan, potensi, bakat, dan minat mereka melalui kegiatan yang secara khusus diselenggarakan oleh pendidik dan atau tenaga kependidikan yang berkemampuan dan berkewenangan di satuan pendidikan. Kegiatan ekstrakurikuler berfungsi untuk mengembangkan diri, sosial, rekreatif dan persiapan karir siswa melalui prinsip: individual, pilihan, keterlibatan aktif, menyenangkan, etos kerja, dan kemanfaatan sosial.

Secara sederhana, penyebaran dan penanaman nilai dasar dan tujuan pembangunan berkelanjutan/ESD melalui ekstrakurikuler digambarkan dalam bagan berikut.

\section{Penjelasan}

Threatment/Perlakuan $1\left(t_{1}\right)$, yaitu: 1$)$ Penetapan Kebijakan melalui Satuan Pendidikan; 2) Koordinasi lembaga instansi di bidang pendidikan dan pihak terkait di tingkat pusat, provinsi, dan kabupaten/kota; 3) Sosialisasi ke Satuan Pendidikan; 4) Kebijakan pembentukan; dan 5) Tim Pengembang di Satuan Pendidikan.

Threatment/Perlakuan $2\left(t_{2}\right)$, yaitu: 1$)$ Sosialisasi konsep dan operasionalisasi ESD dan 2) Dukungan kebutuhan fasilitas dan dana.

Threatment/Perlakuan $3\left(t_{3}\right)$, yaitu: 1 ) Kebijakan ESD di satuan pendidikan; 2)

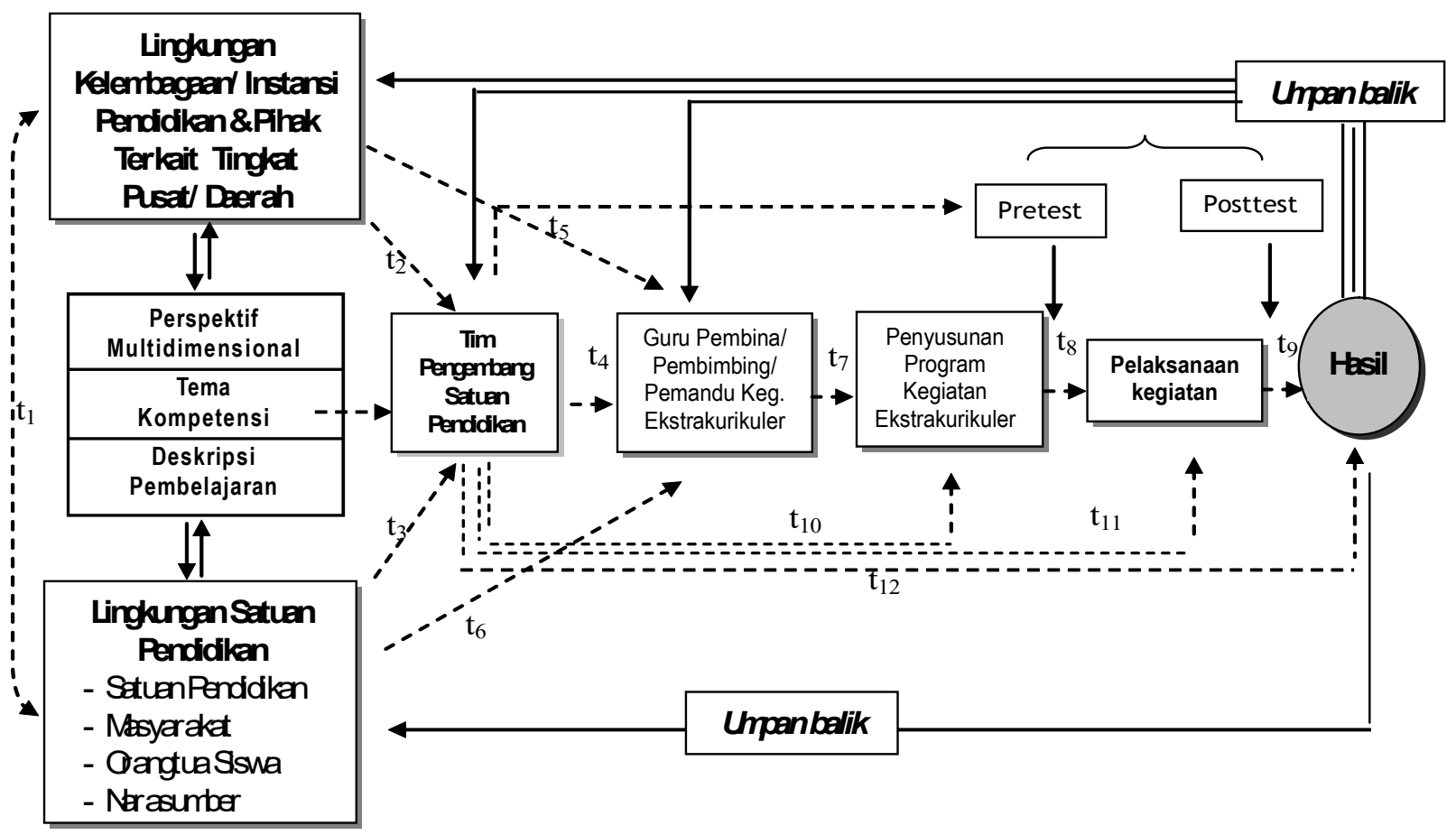

Bagan 5. Model Ekstrakurikuler dalam Penerapan ESD

Keterangan: $\longrightarrow$ = Koordinasi pengembangan ESD di daerah

$--\rightarrow=$ Proses penerapan ESD

$\longrightarrow=$ Umpanbalik (feedback) 
Pembentukan Tim Pengembang, tugas pokok dan fungsi yang dijalankan; 3) Pembinaan kerjasama dan dukungan orangtua siswa dan masyarakat; 4) Pembinaan materi dari narasumber yang relevan; dan 5) Dukungan sarana-prasarana dan fasilitas.

Threatment/Perlakuan $4\left(\mathrm{t}_{4}\right)$, yaitu: 1$)$ Sosialisasi konsep dan materi kepada Guru Pembina/Pembimbing/Pemandu kegiatan ekstrakurikuler (penjelasan, pelatihan, bimbingan, dan lain-lainnya) dan 2) Dukungan dan bantuan sarana-prasarana, fasilitas, dan dana kegiatan.

Threatment/Perlakuan $5\left(t_{5}\right)$, yaitu: 1$)$ Sosialisasi konsep dan materi ESD dan 2) Dukungan sarana-prasarana dan fasilitas kebutuhan kegiatan ekstrakuler.

Threatment/Perlakuan $6\left(t_{6}\right)$, yaitu: 1$)$ Dukungan sarana-prasarana dan fasilitas kebutuhan kegiatan ekstrakuler; 2) Sosialisasi konsep dan materi pembelajaran; dan 3) Keterlibatan narasumber dalam memberikan bimbingan dan mengintegrasikan ke dalam kegiatan ekstrakurikuler.

Threatment/Perlakuan $7\left(t_{7}\right)$, yaitu: 1$)$ Penentuan jenis kegiatan ekstrakurikuler; Penyusunan program kegiatan ekstrakurikuler (tujuan, jadwal waktu, langkah kegiatan, metode/ teknik, dan sebagainya); 2) Penyiapan kebutuhan sarana-prasarana dan fasilitas kegiatan ekstrakurikuler; 3) Pengembangan proses evaluasi; dan 4) Pelaksanaan kegiatan ekstrakurikuler.

Threatment/Perlakuan $8\left(\mathrm{t}_{8}\right)$ : Pretest dilakukan Tim Pengembang untuk mengetahui kondisi awal.

Threatment/Perlakuan $9\left(\mathrm{t}_{\mathrm{g}}\right)$ : Posttest dilakukan Tim Pengembang untuk mengetahui kondisi akhir setelah pelaksanaan kegiatan ekstrakurikuler.

Threatment/Perlakuan $10\left(t_{10}\right):$ Pemberian bimbingan/bantuan dalam mengintegrasikan ESD ke dalam kegiatan ektrakurikuler.

Threatment/Perlakuan $11\left(\mathrm{t}_{11}\right)$ : Pemantauan, pengawasan, dan revisi pelaksanaan kegiatan ekstrakurikuler oleh Tim Pengembang.

Threatment/Perlakuan $12\left(\mathrm{t}_{12}\right)$ : Penilaian pencapaian oleh Tim Pengembang, yaitu: 1) Hasil penilaian/evaluasi merupakan umpan balik (feedback) bagi guru; 2) Pembina/pembimbing/ pemandu, tim pengembang, satuan pendidikan, masyarakat, orang tua siswa, dan instansi yang terkait; 3) Hasil penilaian/evaluasi menjadi masukan untuk mewujudkan tindakan revisi seperlunya bagi penyempurnaan pelaksanaan kegiatan berikutnya.

\section{Simpulan dan Saran}

\section{Simpulan}

Pembangunan berkelanjutan terkait dengan nilai dasar dan tujuan dari multidimensional pembangunan nasional, terutama guna mempertahankan, menjaga, merawat, dan meningkatkan dampak positif pelaksanaan pembangunan serta berupaya mengeliminir dampak negatif yang ditimbulkan. Melalui pendidikan, merupakan unsur strategis dalam upaya penyebaran nilai dasar dan tujuan yang terkandung dalam segenap dimensi pembangunan, sehingga benar-benar dapat dirasakan manfaatnya bagi perbaikkan dan kemajuan hidup masyarakat Indonesia yang berkesinambungan.

\section{Saran}

Konsep dan model pendidikan pembangunan berkelanjutan melalui perspektif multidimensional masih berupa pemikiran di atas meja, belum mengalami pengujicobaannya dan pemantapannya. Pemikiran yang diajukan pun dilandasi prinsip mengintegrasikan ke dalam kegiatan intrakurikuler dan ekstrakurikuler, mengingat belum adanya dasar hukum maupun kebijakan yang kuat yang mendukung penerapan nilai dasar dan tujuan ESD di satuan pendidikan. Sejalan dengan itu, sejumlah saran dikemukakan sebagai berikut. Pertama, perlu pengembangan lebih lanjut untuk mengidentifikasi nilai-nilai yang terkandung dalam segenap dimensi pembangunan, menjabarkan ke dalam komponen, tema (nilai dasar dan tujuan), kompetensi, serta deskripsi pembelajaran agar dapat dijadikan acuan dalam menyebarkan dan menanamkan melalui pendidikan. Kedua, penerapan ESD di bidang pendidikan saat ini hanya dimungkinkan dengan cara mengintegrasikan ke dalam kegiatan intrakurikuler dan ekstrakurikuler. Hal itu mengingat belum adanya dasar hukum maupun kebijakan yang dapat dijadikan acuan untuk mendukung penerapan ESD melalui 
pendidikan. Pengintegrasian itupun disadari akan lebih membebani tugas sekolah dan guru khususnya, serta kurang menjamin secara maksimal penerapannya. Oleh karena itu, upaya mengintegrasikan ESD dalam bidang bidang pendidikan harus dipandang sebagai cara yang bersifat temporer. Dalam jangka panjang, mengingat kompleksitas dan kepentingan penyebaran dan penanaman nilai dasar dan tujuan pembangunan berkelanjutan, perlu dipikirkan untuk menjadikannya sebagai suatu mata pelajaran tersendiri. Namun hal ini baru akan terealisasi apabila didukung oleh perangkat peraturan dan kebijakan yang memadai, terutama terakomodasi dalam perundangan mengenai sistem pendidikan nasional. Pemberian dasar hukum masih merupakan pekerjaan rumah yang perlu diselesaikan oleh pihak yang berkompeten.

\section{Pustaka Acuan}

Foster, George M., 1973. Tradisional Technology and Society Changes, New York: Mc. Milan

Inkeles, Alex., David H. Smith, 1974. Becoming Modern, Individual Changein Six Developing Centries, Cambridge: Harvard University Press.

Myrdal, Gunnar, 1973. Against the Stream, New York: The Mac Millan Press

Parsons, Talcott, 1971. The Social System, New York: Macmillan

Tilaar, H.A.R., 2004. Paradigma Baru Pendidikan Nasional, Jakarta: Rineka Cipta

Undang-Undang Republik Indonesia Nomor 20 Tahun 2003 